\title{
A deep subaqueous fan depositional model for the Palaeoarchaean (3.46 Ga) Marble Bar Cherts, Warrawoona Group, Western Australia
}

\author{
NICOLAS OLIVIER* $\ddagger \dagger$, GILLES DROMART* $\ddagger \S$, NICOLAS COLTICE*

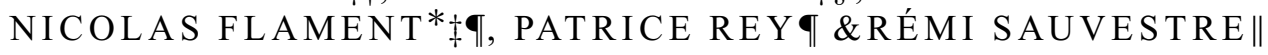 \\ *Université de Lyon, Lyon, France \\ †CNRS UMR 5276 Laboratoire de géologie de Lyon, Université Lyon 1, Villeurbanne, France \\ $\S$ ChemCam team, Mars Science Laboratory project \\ 『Earthbyte Group, School of Geosciences, The University of Sydney, NSW 2006, Australia \\ $\|$ Ecole Normale Supérieure de Lyon, Lyon, France
}

(Received 10 June 2011; accepted 30 January 2012; first published online 2 April 2012)

\begin{abstract}
The 3.46 Ga Marble Bar Chert Member of the East Pilbara Craton, Western Australia, is one of the earliest and bestpreserved sedimentary successions on Earth. Here, we interpret the finely laminated thin-bedded cherts, mixed conglomeratic beds, chert breccia beds and chert folded beds of the Marble Bar Chert Member as the product of low-density turbidity currents, high-density turbidity currents, mass transport complexes and slumps, respectively. Integrated into a channel-levee depositional model, the Marble Bar Chert Member constitutes the oldest documented deep-sea fan on Earth, with thin-bedded cherts, breccia beds and slumps composing the outer levee facies tracts, and scours and conglomeratic beds representing the channel systems.
\end{abstract}

Keywords: Archaean, chert, deep-sea fan, Marble Bar

\section{Introduction}

Sedimentary deposits of the Palaeoarchaean greenstones of the East Pilbara Craton, Western Australia, are of particular geological significance for hosting the oldest putative microfossils (Schopf, 1993; Schopf et al. 2002), the oldest stromatolites (Allwood et al.2006; Van Kranendonk, 2006) and preserving evidence of the environmental conditions of the Early Earth (Robert \& Chaussidon, 2006; Hoashi et al. 2009; van den Boorn et al. 2010). Among these rocks, the $c .3460$ Ma Marble Bar Chert Member of the Duffer Formation (Warrawoona Group) is a typical Archaean red-white-grey banded chert remarkably exposed at the Marble Bar Pool and Chinaman Pool localities (Fig. 1; Buick \& Barns, 1984; Van Kranendonk, 2006). Previous studies on the sedimentary rocks of the Marble Bar Chert Member focused on the chemical and thermal conditions associated with the precipitation of these cherts (Sugitani, 1992; Minami et al. 1995; Kojima et al. 1998; Orberger et al. 2006; van den Boorn et al. 2007, 2010). However, the depositional environment and the mode of formation of the Marble Bar Cherts remain subject to debate, and both hydrothermal environments on a mid-oceanic ridge and large submarine caldera settings have been proposed (Oliver \& Cawood, 2001; Kato \& Nakamura, 2003; Van Kranendonk, 2006; Hoashi et al. 2009; van den Boorn et al. 2010). Hoashi et al. (2009) argued that the haematite grains in the Marble Bar Cherts precipitated directly when hydrothermal fluids of temperature greater than $60{ }^{\circ} \mathrm{C}$ and rich in reduced iron mixed rapidly with seawater containing oxygen in a submarine volcanic depression at depths between $200 \mathrm{~m}$ and $1000 \mathrm{~m}$. Supporting evidence for such a deep environment for the Marble Bar Chert Member is at best indirect, based on the absence of sedimentological or volcanic features characteristic of shallow water settings (Hoashi et al. 2009). The presence of oxygen in deep water strongly questions current thinking about anoxia throughout the Archaean, making essential the scrutiny of the Marble Bar Chert Member depositional setting (Konhauser, 2009). The present contribution provides a comprehensive description of the sedimentary facies and structures of the Marble Bar Chert Member, along with a depositional model to identify the environmental setting of these ancient rocks. We conclude that the sedimentary rocks of the Marble Bar Chert Member were deposited in a deep-sea fan at the toe of an emerged continental mass and that most of these ancient sediments were subjected to short- to long-distance transport.

\section{Geological setting}

The Pilbara Block (Western Australia) consists of a granitegneiss complex and surrounding greenstone belt (Hickman, 1983). The 3.53-3.165 Ga East Pilbara Terrane, i.e. the ancient nucleus of the Pilbara Craton, is composed of the Pilbara Supergroup, which consists of four volcanosedimentary groups (Van Kranendonk et al. 2007). The lower part of the Pilbara Supergroup is represented by the 3.515-3.427 Ga Warrawoona Group, which recorded prehnite-pumpellyite to greenschist-facies metamorphism (Hickman, 1983; Van Kranendonk et al. 2007). This Group consists of ultramafic, tholeiitic, felsic lavas and volcaniclastic rocks with subordinate cherts. The Marble Bar Chert Member occurs at the top of the 3.472-3.465 Ga Duffer Formation and is overlain by the Apex Basalt Formation (Van Kranendonk, 2006). This Member is best exposed at 

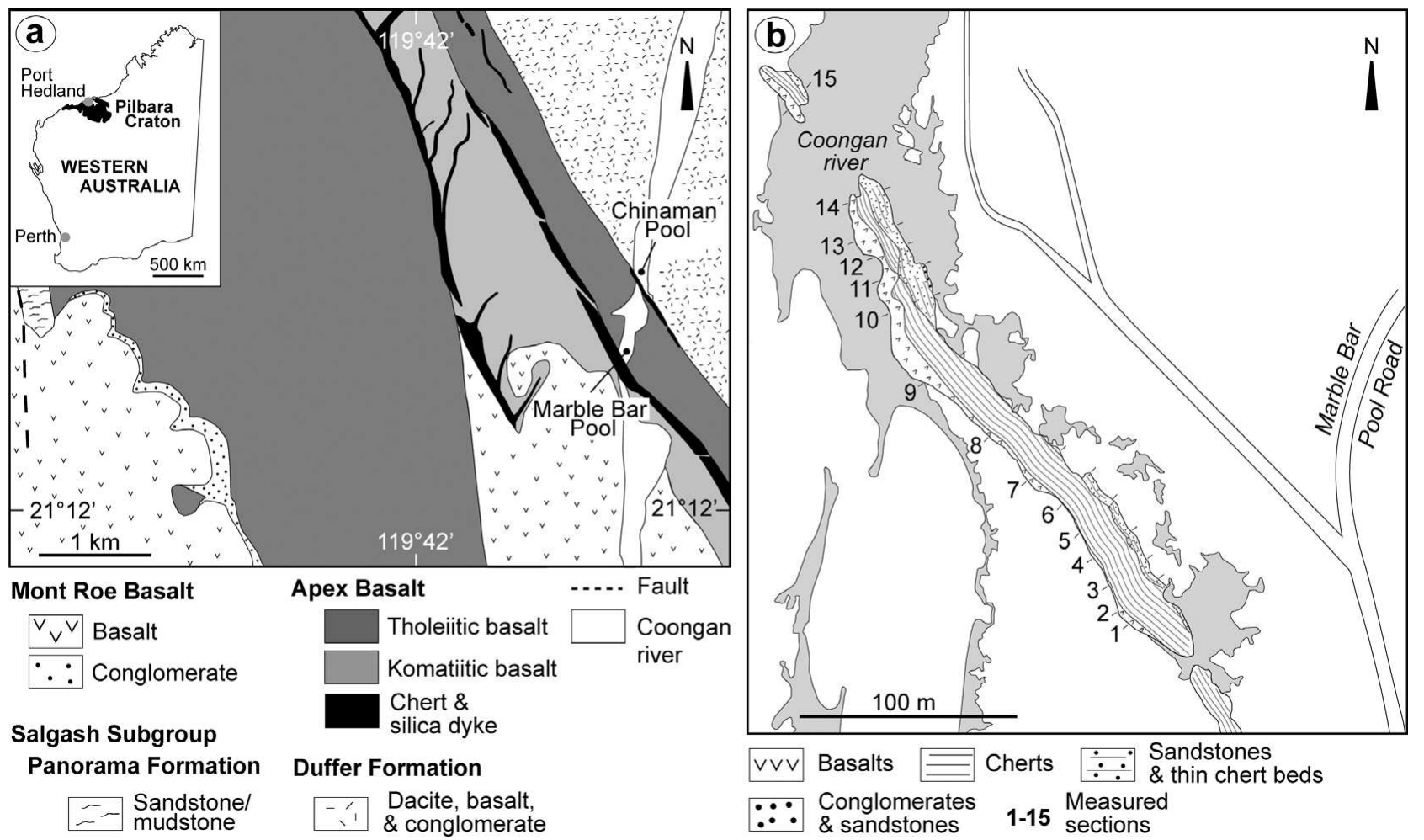

Figure 1. Exposure of the Marble Bar Cherts at Chinaman and Marble Bar pools. (a) Geological map of the Marble Bar area (simplified after Kato \& Nakamura, 2003). (b) Simplified geological map of the Chinaman Pool area showing locations of measured sections.

the Marble Bar Pool and Chinaman Pool localities (Fig. 1), $0.5 \mathrm{~km}$ away from one another, about $3 \mathrm{~km}$ west of Marble Bar.

The Marble Bar Chert Member is a well-preserved unit of centimetre-scale layered red, white and dark-blue chert up to 200 m thick (Hickman, 1983; Van Kranendonk, 2006). This Member displays important thickness variations that repeat at regular intervals over the $30 \mathrm{~km}$ long band along which it crops out (Hoashi et al. 2009). At the Chinaman Pool and Marble Bar Pool localities, the deposits of the Marble Bar Chert Member, preserved between units of pillow basalt and dipping $70^{\circ} \mathrm{E}$, are interpreted as being overturned (Van Kranendonk, 2006). The Marble Bar Chert Member displays a well-marked stratigraphic zoning with predominant white and dark-blue chert in the lower part of the unit whereas the uppermost third of the unit displays more dominant red cherts (Kato \& Nakamura, 2003; Van Kranendonk, 2006; Hoashi et al. 2009).

\section{Chinaman Pool and Marble Bar Pool chert facies}

A spectacular colour banding is exposed throughout the c. $50 \mathrm{~m}$ thick lower Marble Bar Pool section, with the alternation of red, white and dark-blue cherts (Kato \& Nakamura, 2003; Van Kranendonk, 2006). Red and darkblue coloured bands are largely dominant over milky white horizons. These contrasting colourations are due to differing amount of minute haematite inclusions in the microquartz matrix of the chert (Buick \& Barns, 1984), with some subtle grain size variation of the microquartz visible microscopically (Oliver \& Cawood, 2001). Red bands are dusted throughout by tiny specks of haematite, goethite, opaque minerals and rhombic carbonate and possible altered bands of pyrite and magnetite (Sugitani,
1992). Haematite-rich microbands of the uppermost section, i.e. Zones IV and V of Archaean Biosphere Drilling Project (ABDP) site 1 (Hoashi et al. 2009), are parallel to the bedding plane and vary from $\sim 0.01 \mathrm{~mm}$ to $\sim 1 \mathrm{~mm}$ in thickness and $<1 \mathrm{~cm}$ to $>10 \mathrm{~m}$ in lateral extent. The microbands are composed of discrete particles $(0.1-0.6 \mu \mathrm{m}$ in diameter) and clusters $(0.001-0.1 \mathrm{~mm}$ in diameter) of haematite. Dark-blue bands, which are common in the lower section, contain microscopic carbonaceous material (kerogen; Sugitani, 1992). The siderite-rich, lowermost zone described by Hoashi et al. (2009) in ABDP site 1 is not exposed at the surface. The most complete section of the Marble Bar Chert Member is located at Chinaman Pool. It is composed of two very distinctive sub-units: (1) a well-bedded, evenly and finely flat-laminated lower section characterized by a conspicuous red-white-dark-blue banded facies, and prominent brecciated beds locally referred to as 'stick beds' (Hickman \& Lipple, 1978; Hickman, 1983); and (2) an upper section composed of interbedded chert layers and clastic deposits made of coarse felsic grains (Fig. 1b). At Marble Bar Pool, there is a unique chert unit preserved between two pillow basalt units. It is not clear whether the Marble Bar Chert Member of Chinaman Pool and Marble Bar Pool are part of the same chronostratigraphic unit. Nevertheless, the comparison of lithologies, fabrics and facies at both sites points to comparable depositional environments.

The thin-bedded chert facies consist of $0.05-0.40 \mathrm{~m}$ thick, evenly and finely laminated beds of dark-blue or red cherts (Fig. 2a, b). Lamination is only observed in red and darkblue cherts and is defined by millimetre-scale variations in granularity and colour (Sugitani, 1992; Van Kranendonk, 2006). Beds of red and dark-blue cherts laterally pinch out as tapered flow margins and sometimes overlie clastsupported layers. Sub-planar, undulose, parallel laminations 


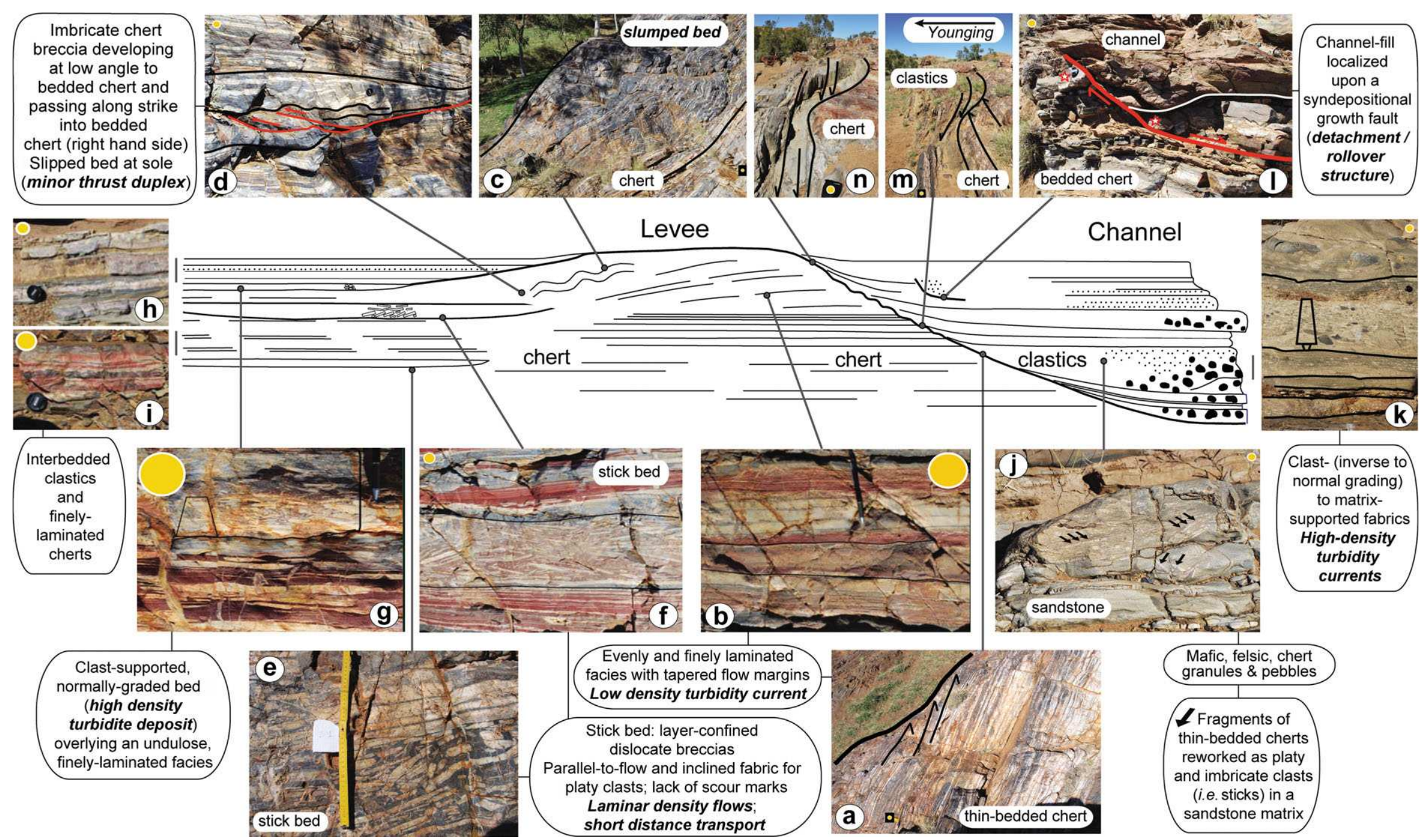

Figure 2. (Colour online) The channel-levee depositional model for the Marble Bar Chert Member showing illustrations of the associated depositional facies. Orange dots are $5 \mathrm{~cm}$ across. 

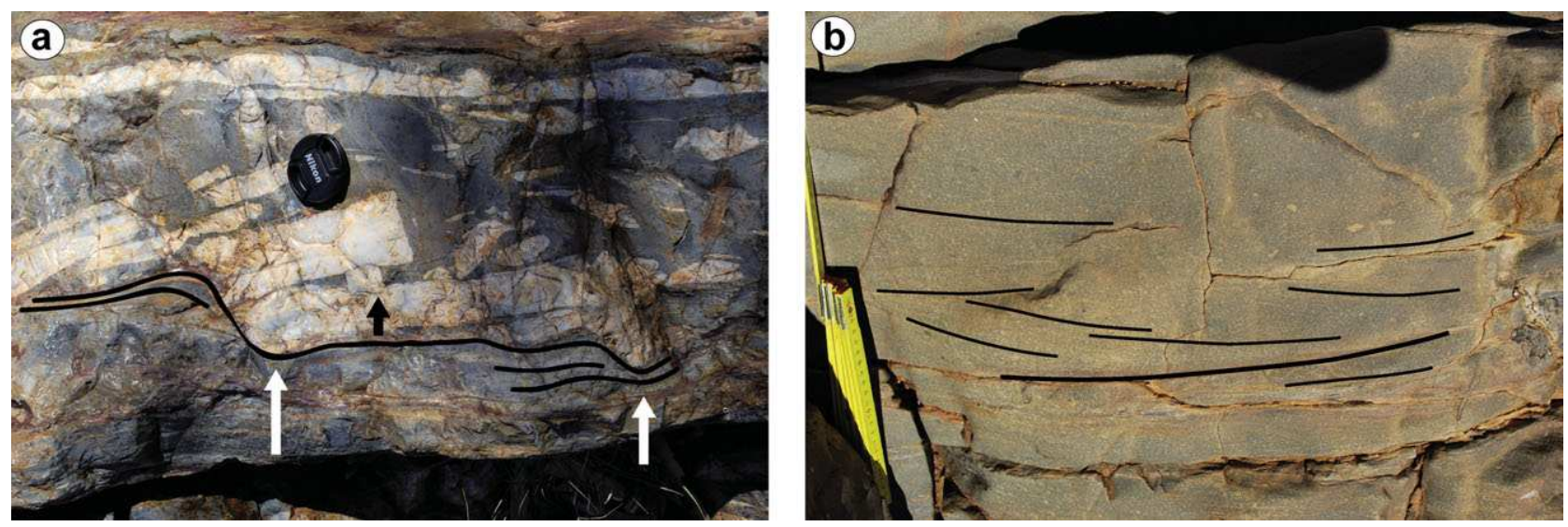

Figure 3. (Colour online) (a) Intra-formational breccia from the Chinaman Pool section: monogenic, early-lithified chert clasts inducing load casts during differential compaction (arrows). (b) Trough cross-bedding in a coarse sand- to granule-size clastic deposit (upper section of the Marble Bar Chert Member at Chinaman Pool).

of red and dark-blue cherts are characteristic of tracted and suspended-load flows of low-density currents. The thinbedded chert facies are interpreted as fine-grained turbidites (e.g. Piper \& Stow, 1991). They make up most of the lower Marble Bar Chert Member and are only sporadically present in the upper Marble Bar Chert Member.

The beds of the lower Marble Bar Chert Member, up to a few metres thick, contain bed-confined asymmetric folds, disharmonic folds and typical slump boudins (Fig. 2c). Folds are not recumbent and trains have not been observed. Locally, beds either pinch out laterally over a distance of a few metres or display thickening due to minor thrust duplexes (Fig. 2d). All of these features are indicative of post-depositional, layerconfined deformation of semi-consolidated sediments related to cohesive, gravity-driven mass-transports. Slumped beds are restricted to the lower Marble Bar Chert Member.

There are two modes of formation for chert breccia material in the lower Marble Bar Chert Member: (1) late breccia bands and hydrothermal fault arrays at high angles to the bedding (Oliver \& Cawood, 2001); (2) breccia beds conformable or at a low angle to bedded chert and referred to as 'stick beds'. The 'stick beds' of the Marble Bar Chert Member are typically $0.1-0.5 \mathrm{~m}$ thick (Fig. 2e-g). Some beds display marked changes in thickness, pinching and swelling at irregular intervals. Bed thickness commonly doubles at swells. The 'stick beds' are completely layer-confined (Fig. 2f). They commonly exhibit sharp and conformable basal boundaries with local compaction of underlying lithologies by clasts (Fig. 3a). The 'sticks' are angular, sharp-edged, elongated and platy clasts $(\mathrm{L} / \mathrm{H}>10)$ of milky white chert. They are monogenic, of a lithology similar to the underlying ribbon chert. Clasts are typically arranged in spectacular shingle-like imbrications (long axis sub-parallel to the bedding or inclined $15-35^{\circ}$ ) and locally in angular folds (Fig. 2e). Some of the 'stick beds' show normal grading (Fig. 2f, g). The 'stick beds' are intra-formational breccias, resulting from the fragmentation of shallow-buried, early-lithified beds with limited displacement of clasts. In addition to slump folds and boudins, the textural gradation from slumps to breccia beds suggests that the breccia beds are dismembered slumps. The fabric of the 'stick beds' is strikingly similar to that of carbonate breccia beds of deep-water slope environments in Phanerozoic sequences (Dromart, Ferry \& Atrops, 1993; Robin et al. 2010). The 'stick beds' are mainly observed in the uppermost section of the lower Marble Bar Chert Member. Other types of breccia beds have been recognized in the Marble Bar Chert
Member. They consist of layers of variably elongated $(1 \leq$ $\mathrm{L} / \mathrm{H}<10$ ) pebble- to granule-sized intra-formational white chert clasts locally displaying normal grading, and locally capped by thin-bedded cherts (i.e. finely laminated beds of red and dark-blue cherts). These observations suggest that depositional processes for chert breccia beds, including 'stick beds', vary from: (1) slumps to, (2) unchannelized mass transport complexes (i.e. cohesive debris flows with only minor evidence of erosion and sporadic evidence of organization as clast imbrications), to, (3) high-density turbidity currents (i.e. non-graded to graded, clast-supported layers overlain by laminated, turbulent flow fabrics).

The upper section of the Marble Bar Chert Member at Chinaman Pool consists of coarse-grained siliciclastic sequences with recurrent thin-bedded cherts (Fig. 2h, i). 'Sticks' of typical milky white chert are observed as floating clasts in a coarse-grained siliciclastic matrix (Fig. 2j). Other lithoclasts of these mixed conglomeratic beds consist of mixed granule- to pebble-sized rounded fragments of mafic (basalt) and felsic (granodiorite) rocks. Sedimentary structures include metre-scale moderately incised channels and some trough cross-beds (Figs 2n, 3b). Inverse to normal grading, multilayering, clast imbrication and outsized clasts are common features (Fig. 2k). We interpret these deposits, except the thin-bedded cherts, to be typical high-density turbidites.

An unambiguous metre-scale syn-depositional growth fault is located in the upper section of Chinaman Pool. It consists of a normal, listric fault sealed upwards by chert beds and passing downwards to a sub-horizontal shear zone (Fig. 21). The hanging wall block is affected by a typical rollover anticline and supports a sand-filled channel created by the listric fault collapse. This syn-depositional feature makes it an unmistakable stratigraphic polarity criterion. In addition, it suggests that the unconformable surface that bounds the lower and upper Marble Bar Chert Member and shows truncation and onlap stratal termination features (Fig. $2 \mathrm{~m}$ ) was generated by the collapse of a much larger listric fault.

\section{A channel-levee depositional model for the Marble Bar Chert Member}

The set of facies and sedimentary structures, including unconformable surfaces, observed in the Marble Bar Chert Member describes a general channel-levee depositional 
system (Fig. 2), such as originally described by Mutti (1977). In these gravity-driven depositional systems, the levees of the subaqueous channel-levee systems form from the overbanking of predominantly fine-grained sediment (silts and clays) because of the spillover of turbulent flows as they move down the channel system (Mutti \& Normark, 1987; Piper \& Deptuck, 1997). Colour-banded mud and clay are the most common sedimentary facies within the overbank deposits, with rare interbeds of coarser sediment composed of silt-size particles occurring in laminae and sharp-based thin beds (Normark \& Damuth, 1997). Conversely, channel deposits consist of thick-bedded coarse facies including structureless to chaotic sand beds, graded and cross-bedded sand beds (normal grain size grading is predominant and many graded sand beds grade upwards through silt to clay at the top), plus chaotic mud (mud clasts deriving from localized sediment failure from inner levees). The channel deposits of the Marble Bar Chert Member are dominated by coarse-grained siliciclastic rocks. The internal geometry of the channel-fill deposits indicates that the channels were cut prior to and during their infilling. The bedding surfaces of the upper and lower channel deposits tend to be parallel to the flat channel tops and to the irregular channel floors, respectively. Bedding surfaces of lower channel deposits gradually onlap the basal channel surface. Slumping, other mass-flows and late fracture-related deformation have removed the original dip of the levee beds. The bedded cherts of the Marble Bar Chert Member appear to have been indurated before burial compaction, probably very early, at the time of sea-floor exposure. The best supportive evidence for early lithification of these cherts comes from the occurrence of cherts as reworked clasts in the mixed conglomeratic facies (Fig. 2j) and from load cast features due to differential compaction of distinctively indurated material (Fig. 3a). Owing to early lithification, siliceous levee slopes may display a higher angle of repose than typical modern siliciclastic subaqueous levees do ( $5^{\circ}$ at best; e.g. Gervais et al. 2001; Migeon et al. 2001; Broucke et al. 2004). Slope over-steepening by early lithification combined with slope overloading by high sediment flux on the channel levee would explain the frequent occurrence of slumping and other mass gravity flows observed in the lower Marble Bar Chert Member sequence. Hence, the slumped beds, mass-flow deposits, turbidite beds and growth faults make a comprehensive assortment of gravity-driven sedimentary processes in a slope environment.

\section{Discussion}

In the Marble Bar Chert Member, polymictic conglomeratic and pebbly-sandstone units, including granodiorite and basaltic sources, characterize the channel deposits of the channel-levee depositional model (Fig. 2). This suggests that these $3.456 \mathrm{Ga}$ sediments were deposited at the toe of emerged and differentiated continental lands, which is consistent with the oldest angular unconformity reported in the East Pilbara Craton (Buick et al. 1995). Thus, the deposits of the Marble Bar Chert Member were not related to a mantle plume as suggested by Kato \& Nakamura (2003), nor to mid-ocean ridges and active spreading centres, as proposed by Lascelles (2007). In the northern part of the Marble Bar greenstone belt (Fig. 1), the youngest 3.458-3.427 Ga Panorama Formation consists of mudstones and sandstones also interpreted as representing turbidites near a continental margin of a differentiated and evolved continent (Kato \& Nakamura, 2003). The only known deep gravity-driven deposits on Earth older than that of the Marble Bar Chert Member are 3700 to $3800 \mathrm{Ma}$ normally graded sandstone layers interpreted as turbidites from the Isua greenstone belt (Rosing, 1999). These sedimentary rocks have been strongly metamorphosed to at least amphibolite-facies conditions and are strongly deformed (Nutman, 2006). Thus, complete turbiditic sequences at Isua remain rare and could result from depositional mechanisms other than turbidity flows (Fedo, Myers \& Appel, 2001). These putative Isua turbidites are devoid of terrigenous clastic sediments, implying deposition in an oceanic environment in the vicinity of volcanic edifices (Rosing, 1999). Because the Marble Bar Chert Member yields a low-grade metamorphism (Van Kranendonk et al. 2007), it preserves a unique set of facies documenting the earliest deep-sea fan on Earth.

Modern channel-levee complexes are observed in the middle section of deep-water fans downstream of the continental slope break, at very variable water depth (500 3000 m; Richards, Bowman \& Reading, 1998). Additional sedimentary structures, e.g. wave-driven deposits such as hummocky and swaley cross-beds, that would further constrain the water depth were not observed. Thus, a depth range of 200 to $1000 \mathrm{~m}$ proposed for the depositional setting of the Marble Bar Chert Member (Hoashi et al. 2009) appears to be minimal.

The red cherts of the Marble Bar Chert Member are made of silt-sized clusters of haematite crystals (Sugitani, 1992; Hoashi et al. 2009). Hoashi et al. (2009) argued that these haematite crystals are primary and precipitated when hot hydrothermal fluids $\left(>60^{\circ} \mathrm{C}\right)$, rich in reduced iron, mixed rapidly with seawater containing oxygen. Such a process for the oxidation of dissolved ferrous (reduced) iron, entering the oceans from hydrothermal vents, questions the common view of widespread anoxia throughout the early Archaean (Konhauser, 2009). In our proposed deep subaqueous depositional model for the Marble Bar Chert Member, these haematite particles may not be in situ sediments. Whatever their mechanism of formation, i.e. transformation of a precursor lithology or direct precipitation from a silica-rich fluid (cf. Van den Boorn et al. 2007), dark-blue and red cherts were formed in superficial environments and transported downslope by density currents. This challenges the view of Hoashi et al. (2009) that Palaeoarchaean deep (>200 m) bottom ocean waters were at least locally oxidizing.

Acknowledgements. This work was supported by a grant from CNRS-PID OPV and the ChemCam program, Mars Science Laboratory project. NF acknowledges a Lavoisier grant from the French Ministry of Foreign and European Affairs. PR, NF and NC acknowledge an IPDF grant from the University of Sydney. The careful reviews of two anonymous reviewers greatly improved this manuscript.

\section{References}

Allwood, A. C., Walter, M. R., Kamber, B. S., MARShall, C. P. \& BURCH, I. 2006. Stromatolite reef from the Early Archaean era of Australia. Nature 441, 714-18.

Broucke, O., Temple, F., Rouby, D., Robin, C., Calassou, S., Nalpas, T. \& Guillocheau, F. 2004. The role of deformation processes on the geometry of muddominated turbiditic systems, Oligocene and LowerMiddle Miocene of the Lower Congo basin (West African Margin). Marine and Petroleum Geology 21, 321-48.

BUICK, R. \& BARNS, K. R. 1984. Cherts in the Warrawoona Group: Early Archean silicified sediments deposited in shallow-water environments. University of Western 
Australia, Geological Department \& University Extension, Publication 9, 37-53.

Buick, R., Thornett, J. R., McNaughton, N. J., SMith, J. B., BARley, M. E. \& SAVAge, M. 1995. Record of emergent continental crust $\sim 3.5$ billion years ago in the Pilbara Craton of Australia. Nature 375, 574-7.

DromART, G., FERRY, S. \& ATROPS, F. 1993. Allochtonous deep-water limestone conglomerates and relative sealevel changes: the Upper Jurassic-Berriasian of SouthEast France. In Sequence Stratigraphy and Facies Associations (eds H. Posamentier, C. Summerhayes \& G. P. Allen), pp. 295-305. International Association of Sedimentologists Special Publication no. 18.

Fedo, C. M., Myers, J. S. \& APpel, P. W. U. 2001. Depositional setting and paleogeographic implications of earth's oldest supracrustal rocks, the $3.7 \mathrm{Ga}$ Isua Greenstone belt, West Greenland. Sedimentary Geology 141-142, 61-77.

Gervais, A., Mulder, N., Savoye, B., Migeon, S. \& CREMER, M. R. 2001. Recent processes of levee formation on the Zaire deep-sea fan. Comptes Rendus de l'Académie des Sciences de Paris 332, 371-8.

HickMAN, A. H. 1983. Geology of the Pilbara Block and its environs. Western Australia Geological Survey Bulletin 127, 1-268.

HickMAN, A. H. \& LipPle, S. L. 1978. Explanatory Notes on the Marble Bar 1:250 000 Geological Sheet, Western Australia. Perth: Geological Survey of Western Australia, $24 \mathrm{pp}$.

Hoashi, M., Bevacqua, D. C., Otake, T., Watanabe, Y., Hickman, A. H., UtSUNOMIYA, S. \& OHMOTO, H. 2009. Primary haematite in an oxygenated sea 3.46 billion years ago. Nature Geosciences 2, 301-6.

KATO, Y. \& NAKAMURA, K. 2003. Origin and global tectonic significance of Early Archaean cherts from the Marble Bar greenstone belt, Pilbara Craton, Western Australia. Precambrian Research 125, 191-243.

KoJima, S., Hanamuro, T., Hayashi, K., Haruna, M. \& OHмOто, H. 1998. Sulphide minerals in Early Archaean chemical sedimentary rocks of the eastern Pilbara district, Western Australia. Mineralogy and Petrology 64, 219-35.

KonHAuser, K. 2009. Deepening the early oxygen debate. Nature Geosciences 2, 241-2.

LASCELLES, D. L. 2007. Black smokers and density currents: a uniformitarian model for the genesis of banded iron-formations. Ore Geology Reviews 32, 381-411.

Migeon, S., Savoye, B., Zanella, E., Mulder, T., FAUGÈRES, J.-C. \& WEBER, O. 2001. Detailed seismicreflection and sedimentary study of turbidite sediment waves on the Var Sedimentary Ridge (SE France): significance for sediment transport and deposition and for the mechanisms of sediment-wave construction. Marine and Petroleum Geology 18, 179-208.

MinAmI, M., SHIMIZU, H., MASUDA, A. \& ADACHI, M. 1995. Two Archean Sm-Nd ages of 3.2 and 2.5 Ga for the Marble Bar Chert, Warrawoona Group, Pilbara Block, Western Australia. Geochemical Journal 29, 34762.

MUTTI, E. 1977. Distinctive thin-bedded turbidite facies and related depositional environments in the Eocene Hecho Group (south-central Pyrenees, Spain). Sedimentology 24, 107-31.

MutTI, E. \& NORMARK, W. R. 1987. Comparing examples of modern and ancient turbidite systems. In Marine Clastic Sedimentology (eds J. K. Legett \& G. G. Zuffa), pp. 138. London: Graham \& Trotman.
Normark, W. R., Damuth, J. E. \& The Leg 155 SEDIMENTOLOGY GROUP. 1997. Sedimentary facies and associated depositional elements of the Amazon Fan. In Proceedings of the Ocean Drilling Program, Scientific Results, vol. 155 (eds R. D. Flood, D. J. W. Piper, A. Klaus \& L. C. Peterson), pp. 611-52. College Station, Texas.

Nutman, A. P. 2006. Antiquity of the oceans and continents. Elements 2, 223-7.

Oliver, N. S. H. \& CAWOOD, P. A. 2001. Early tectonic dewatering and brecciation on the overturned sequence at Marble Bar, Pilbara Craton, Western Australia: domerelated or not? Precambrian Research 105, 1-15.

Orberger, B., Rouchon, V., Westall, F., De Vries, S. T., Pinti, D. L., Wagner, C., Wirth, R. \& HASHIZUME, K. 2006. Microfacies and origin of some Archean cherts (Pilbara, Australia). In Processes on the Early Earth (eds W. U. Reimold \& R. L. Gibson), pp. 133-56. Geological Society of America Special Paper no. 405.

PIPER, D. J. W. \& DePTUCK, M. 1997. Fine-grained turbidites of the Amazon fan: facies characterization and interpretation. In Proceedings of the Ocean Drilling Program, Scientific Results, vol. 155 (eds R. D. Flood, D. J. W. Piper, A. Klaus \& L. C. Peterson), pp. 79-108. College Station, Texas.

PIPER, D. J. W. \& STOW, D. A. V. 1991. Fine-grained turbidites. In Cycles and Events in Stratigraphy (eds G. Einsele, W. Ricken \& A. Seilacher), pp. 360-66. New York: Springer-Verlag.

RichARDS, M., BOWMAN, M. \& READING, H. 1998. Submarine-fan systems I: characterization and stratigraphic prediction. Marine and Petroleum Geology 15, 689-717.

Robert, F. \& CHAUssidon, M. 2006. A palaeotemperature curve for the Precambrian oceans based on silicon isotopes in cherts. Nature 443, 969-72.

Robin, C., Gorican, S., Guillocheau, F., Razin, P., Dromart, G. \& Mosaffa, H. 2010. Mesozoic deepwater carbonate deposits from the southern Tethyan passive margin in Iran (Pichakun nappes, Neyriz area): biostratigraphy, facies sedimentology and sequence stratigraphy. In Tectonic and Stratigraphic Evolution of Zagros and Makran During the Mesozoic-Cenozoic (eds P. Leturmy \& C. Robin), pp. 179-210. Geological Society of London, Special Publication no. 330.

Rosing, M. T. 1999. 13C-depleted carbon microparticles in $>3700$-Ma sea-floor sedimentary rocks from West Greenland. Science 283, 674-6.

SCHOPF, J. W. 1993. Microfossils of the Early Archean Apex Chert: new evidence of the antiquity of life. Science $\mathbf{2 6 0}$, 640-6.

Schopf, J. W, Kudryavtsev, A. B., Agresti, D. G., WDOWIAK, T. J. \& CZAJA, A. D. 2002. LaserRaman imagery of Earth's earliest fossils. Nature 416, $73-6$.

SUGITANI, K. 1992. Geochemical characteristics of Archean cherts and other sedimentary rocks in the Pilbara Block, Western Australia: evidence for Archean seawater enriched in hydrothermally-derived iron and silica. Precambrian Research 57, 21-47.

VAN DEN BOORN, S. H. J. M., VAN BERGEN, M. J., NiJMAN, W. \& VROON, P. Z. 2007. Dual role of seawater and hydrothermal fluids in Early Archean chert formation: evidence from silicon isotopes. Geology $\mathbf{3 5}$, 939-42.

VAN DEN BoORn, S. H. J. M., VAN BERGEN, M. J., VROON, P. Z., DE VRIES, S. T. \& NiJMAN, W. 2010. Silicon 
isotope and trace element constraints on the origin of $\sim 3.5$ Ga cherts: implications for Early Archaean marine environments. Geochimica et Cosmochimica Acta 74, 1077-103.

VAN KRANENDONK, M. J. 2006. Volcanic degassing, hydrothermal circulation and the flourishing of early life on Earth: a review of the evidence from c. 3490-3240 Ma rocks of the Pilbara Supergroup, Pilbara Craton, Western Australia. Earth Sciences Reviews 74, 197-240.

VAN KRANENDONK, M. J., SMithies, R. H., Hickman, A. H. \& CHAMPION, D. C. 2007. Review: secular tectonic evolution of Archean continental crust: interplay between horizontal and vertical processes in the formation of the Pilbara Craton, Australia. Terra Nova 19, 1-38. 